\title{
Genome sequence of the brown rot fungal pathogen Monilinia fructigena
}

\author{
Lucia Landi ${ }^{1}$, Rita M. De Miccolis Angelini ${ }^{2}$, Stefania Pollastro², Domenico Abate ${ }^{2}$, Francesco Faretra ${ }^{2}$ \\ and Gianfranco Romanazzi ${ }^{1}$ (1)
}

\begin{abstract}
Objectives: Monilinia fructigena (phylum Ascomycota, family Sclerotiniaceae) is a plant pathogen that causes brown rot and blossom blight in pome fruit and stone fruit of the Rosaceae family, which can cause significant losses in the field and mainly postharvest. The aim of this study was to create a high-quality draft of the M. fructigena genome assembly and annotation that provides better understanding of the epidemiology of the pathogen and its interactions with the host(s) and will thus improve brown rot management.

Data description: We report here on the genome sequence of M. fructigena strain Mfrg269 that was collected from plum in southern Italy. This is assembled into 131 scaffolds, with a total size of $43.125 \mathrm{Mb}$, with 9960 unique proteincoding genes. The novel genomic resources allow improved genomic comparisons among the most important pathogens belonging to the Monilinia genus, with the aim being to improve the knowledge of their plant-pathogen interactions, population biology, and control.
\end{abstract}

Keywords: Brown rot, De-novo assembly, Genome annotation, Illumina, Monilinia fructigena, PacBio, Pome fruit, Stone fruit

\section{Objectives}

Monilinia fructigena, Honey ex Whetzel is one of the several apothecial ascomycetes, which primarily include Monilinia laxa (Aderhold and Ruhland) Honey and Monilinia fructicola (G. Winter) Honey [1]. These can cause brown rot and blossom blight, which results in serious economic losses for crops of the Rosaceae family [2]. $M$. fructigena is widespread in Europe, Asia (e.g., Near East, Far East, India), northern Africa, and some parts of South America, and it is a quarantine pathogen in Canada, USA, Australia and New Zealand (http://www.cabi.org/ isc/datasheet/34747). It causes one of the most important diseases on stone and pome fruit trees [3, 4]. Prevalent symptoms are fruit rots in the field and also postharvest.

The aim of this study was to provide new data on the sequence of the $M$. fructigena genome and the annotated protein-coding genes. Here, we report on the $M$. fructigena draft genome obtained using a hybrid assembly approach that exploited the high accuracy of the Illumina next generation sequencing along with the longsize of the Pacific Biosciences (PacBio) third generation sequencing, thus reducing gaps and improving the quality of the draft genome [5]. Our annotated genome draft is larger and of better quality than the publicly available $M$. fructigena genome [6]. Our data reduced the $M$. fructigena assembly to 131 scaffolds without gaps. In addition, the sequence completeness and high coverage were verified by mapping RNA sequencing (RNA-Seq) reads from the same $M$. fructigena strain [7]. The availability of a more accurate genome sequence provides improved opportunities to the scientific community for studies aimed at exploring in more detail the pathogen epidemiology, its host interactions, and the tools to optimise brown rot management.

\footnotetext{
*Correspondence: ritamilvia.demiccolisangelini@uniba.it

${ }^{2}$ Department of Soil, Plant and Food Sciences, University of Bari 'Aldo

Moro', Via G. Amendola 165/A, 70126 Bari, Italy

Full list of author information is available at the end of the article
}

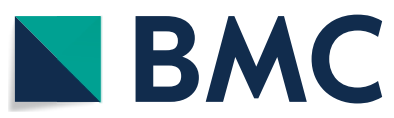

(c) The Author(s) 2018. This article is distributed under the terms of the Creative Commons Attribution 4.0 International License (http://creativecommons.org/licenses/by/4.0/), which permits unrestricted use, distribution, and reproduction in any medium, provided you give appropriate credit to the original author(s) and the source, provide a link to the Creative Commons license, and indicate if changes were made. The Creative Commons Public Domain Dedication waiver (http://creativecommons.org/ publicdomain/zero/1.0/) applies to the data made available in this article, unless otherwise stated. 


\section{Data description}

The data report here (Table 1) are related to the de-novo assembly and annotation of the genome of $M$. fructigena. A monoconidial strain of M. fructigena, Mfrg269, was derived from plum during monitoring of Monilinia populations present on stone fruit in southern Italy (Tursi, Basilicata) [8]. The strain was characterised both at the phenotypic and molecular levels [7-9]. The strain was grown in liquid medium (2\% malt extract; Oxoid) for $36 \mathrm{~h}$ at $24 \pm 1{ }^{\circ} \mathrm{C}$, in darkness and under shaking (150 rpm). Genomic DNA was extracted using Gentra Puregene tissue kits (Qiagen, Milan, Italy), according to the manufacturer instructions. Genome sequencing yielded both short $2 \times 92$-bp paired-end reads (Illumina Sequencing Technology; HiScanSQ platform; SELGE Network Sequencing Service, Bari, Italy) (Table 1, dataset 1; Data Citation 1: National Center for Biotechnology Information (NCBI) Sequence Read Archive SRR7262862) and long 20-kb reads (PacBio Sequencing Technology; RSII platform; Macrogen Inc., Next Generation Sequencing Service, Geumcheongu, Seoul, South Korea) (Table 1, dataset 2; Data Citation 2: NCBI Sequence Read Archive SRR7263013). A hybrid assembly strategy was applied, and all of the reads from both platforms were assembled to produce scaffolds according to the DBG2OLC pipeline [5], with optimized parameters. SparseAssembler [10] was used to preassemble the Illumina short reads into contigs (NodeCovTh, 2; EdgeCovTh, 1; k, 71; g, 15; and PathCovTh, 100). The overlap and layout were performed with module DBG2OLC [5] with the output contig file and $20 \times$ PacBio long reads (AdaptiveTh, 0.001; KmerCovTh, 2; and MiniOverlap, 20). The consensus was then performed using the Sparc module [11] in which BLASR [12] was used to align all of the raw reads to the assembly backbone, with the default settings. The selection of the best draft genome was also carried out by mapping RNA-Seq reads from the same $M$. fructigena strain [8] using the CLC Genomics Workbench v. 7.0.3 software (CLC Bio, Aarhus, Denmark). Gene prediction was performed with Augustus implemented in the BLAST2GO PRO package (v.4.1.9), using Botrytis cinerea as the model species and the RNA-Seq reads as a guide with default settings.

The result was a high-quality annotated gap-free draft genome (Table 1, data file 1; Data citation 3: GenBank QKRW01000001-QKRW01000131). About 83\% of the RNA-Seq reads mapped on the final genome draft version. This had a total size of $43.125 \mathrm{Mb}$ with $42.05 \% \mathrm{GC}$ content, $\sim 210 \times$ sequencing coverage, 131 scaffolds, N50 scaffold length of $767.732 \mathrm{~kb}$, scaffold L50 of 20, and maximum scaffold size of $1,863,841 \mathrm{bp}$. The 10,502 genes, with 10,802 transcripts that coded for 9960 predicted proteins were functionally annotated on the draft genome.

The genome herein described is an improved version of the $M$. fructigena genome as compared to the previously published version obtained by next generation sequencing alone (GCA_002909635.1; genome length: $39.329 \mathrm{Mb}$; coverage: $110 \times$; 1633 scaffolds; scaffold N50: $56.695 \mathrm{~kb}$; L50: 208). These novel genomic resources make feasible better genomic comparisons among the most important pathogens belonging to the Monilinia genus, with the aim to improve knowledge of their phylogenic relationships, plant-pathogen interactions, population biology, and control.

\section{Limitations}

These data report the genome sequence of a single strain of $M$. fructigena obtained by a hybrid approach using next generation sequencing and third generation sequencing and automatic gene prediction, although driven by RNA-Seq reads. An important further step will be the reconstruction of whole chromosomes and the manual curation of the predicted genes and their annotation for better characterization of the genome at both the structural and functional levels. Furthermore, studies on comparative genomics will be feasible when high quality genomic data of other Monilinia species are available.

Table 1 Overview of data files

\begin{tabular}{llll}
\hline Label & Name of data file/dataset & File types (file extension) & Data repository: NCBI accession number \\
\hline Dataset 1 & $\begin{array}{c}\text { SRR7262862 Illumina DNA sequencing of Monilinia } \\
\text { fructigena strain Mfrg269 }\end{array}$ & fastq/fasta files & https://www.ncbi.nlm.nih.gov/sra/SRX4167027 \\
Dataset 2 & $\begin{array}{c}\text { SRR7263013 PacBio DNA sequencing of Monilinia fructi- } \\
\text { gena strain Mfrg269 }\end{array}$ & fastq/fasta files & https://www.ncbi.nlm.nih.gov/sra/SRX4167179 \\
Data file 1 & $\begin{array}{l}\text { QKRW01000001-QKRW01000131 Whole genome shot- } \\
\text { gun sequencing of Monilinia fructigena strain Mfrg269 }\end{array}$ & fasta/GenBank/ASN.1 files & https://www.ncbi.nlm.nih.gov/Traces/wgs/QKRW01 \\
\hline
\end{tabular}




\section{Abbreviations}

NCBI: National Center for Biotechnology Information; PacBio: Pacific Biosciences; RNA-Seq: RNA sequencing.

\section{Authors' contributions}

RMDMA, DA and SP contributed to the molecular biology experiments; LL, RMDMA and DA performed the bioinformatic pipeline for sequencing data analysis, de-novo assembly and gene prediction; RMDMA, LL, submitted the data to Genbank; LL, RMDMA, FF, GR wrote the manuscript; RMDMA, SP, FF, GR planned the project. All authors read and approved the final manuscript.

\section{Author details}

1 Department of Agricultural, Food and Environmental Sciences, Marche Polytechnic University, Via Brecce Bianche 10, 60131 Ancona, Italy. ${ }^{2}$ Department of Soil, Plant and Food Sciences, University of Bari 'Aldo Moro', Via G. Amendola 165/A, 70126 Bari, Italy.

\section{Acknowledgements}

Bioinformatic analysis was partially carried out by using the facilities of the ReCaS data center of the University of Bari (http://www.recas-bari.it).

\section{Competing interests}

The authors declare that they have no competing interests.

\section{Availability of data and materials}

The datasets of Illumina (Data Citation 1: NCBI Sequence Read Archive SRR72 62862) and PacBio (Data Citation 2: NCBI Sequence Read Archive SRR72 63013) DNA sequencing reads and the draft assembly (Data Citation 3: GenBank QKRW01000001-QKRW01000131) related to the Whole Genome Shotgun project generated and analysed during the current study (BioProject PRJNA470675) are available at the NCBI repository, under the Accession Number QKRW00000000. The version described in this paper is the first version, QKRW01000000.

\section{Consent for publication}

Not applicable.

\section{Ethics approval and consent to participate}

Not applicable.

\section{Funding}

The authors acknowledge support from the Marche Polytechnic University for the project "Genome sequencing of Monilinia species", from the University of Bari Aldo Moro for the project "Epidemiology, genetics of plant pathogens and development of molecular diagnostic methods", and from the Apulia Region, PO FESR 2007-2013-Axis I, Line of intervention 1.2., Action 1.2.1 for the project "Laboratory network for the selection, characterization and conservation of germplasm and for preventing the spread of economically-relevant and quarantine pests (SELGE) No. 14".

\section{Publisher's Note}

Springer Nature remains neutral with regard to jurisdictional claims in published maps and institutional affiliations.
Received: 20 June 2018 Accepted: 13 October 2018

Published online: 23 October 2018

\section{References}

1. Mordue JEM. Sclerotinia fructicola, S. fructigena, S. laxa. CMI Descriptions of Pathogenic Fungi and Bacteria. Nos 616, 617, 619. Wallingford, UK: CAB International; 1979.

2. Byrde RJ, Willetts HJ. The brown rot fungi of fruit: their biology and control. Oxford: Pergamon Press; 1977.

3. Jones AL, Aldewinckle HS. Compendium of apple and pear diseases. St. Paul: APS Press; 1990

4. Hrustić J, Grahovac M, Mihajlović M, Delibašić G, Ivanović M, Nikolić M, Tanović B. Molecular detection of Monilinia fructigena as causal agent of brown rot on quince. Pestic Phytomed. 2012;27:15-24. https://doi. org/10.2298/PIF1204283H.

5. Ye C, Hill CM, Wu S, Ruan J, Ma Z. DBG2OLC: efficient assembly of large genomes using long erroneous reads of the third generation sequencing technologies. Sci Rep. 2016;6:1-9. https://doi.org/10.1038/srep31900.

6. Rivera Y, Zeller K, Srivastava SK, Sutherland J, Galvez ME, Nakhla MK, et al. Draft genome resources for the phytopathogenic fungi Monilinia fructicola, M. fructigena, M. polystroma and M. laxa, the causal agents of brown rot. Phytopathology. 2018. https://doi.org/10.1094/phyto-12-17-0418-a.

7. De Miccolis Angelini RM, Abate D, Rotolo C, Gerin D, Pollastro S, Faretra F. De-novo assembly and comparative transcriptome analysis of Monilinia fructicola, Monilinia laxa and Monilinia fructigena, the causal agents of brown rot on stone fruits. BMC Genomics. 2018;19:436. https://doi. org/10.1186/s12864-018-4817-4.

8. Abate D, Pastore C, Gerin D, De Miccolis Angelini RM, Rotolo C, Pollastro S, Faretra F. Characterization of Monilinia spp. populations on stone fruit on South Italy. Plant Dis. 2018. https://doi.org/10.1094/pdis-08-17-1314-re.

9. Abate D, De Miccolis Angelini RM, Rotolo C, Pollastro S, Faretra F. Mating system in the brown rot pathogens Monilinia fructicola. Monilinia laxa and Monilinia fructigena. Phytopathology. 2018. https://doi.org/10.1094/ phyto-03-18-0074-r.

10. Ye C, Ma ZS, Cannon CH, Pop M, Yu DW. Exploiting sparseness in de-novo genome assembly. BMC Bioinform. 2012;13(Suppl 6):S1. https://doi. org/10.1186/1471-2105-13-S6-S1.

11. Ye C, Ma ZS. Sparc: a sparsity-based consensus algorithm for long erroneous sequencing reads. Peer J. 2016;4:e2016. https://doi.org/10.7717/peerj 2016.

12. Chaisson MJ, Tesler G. Mapping single molecule sequencing reads using basic local alignment with successive refinement (BLASR): application and theory. BMC Bioinform. 2012;13:238. https://doi. org/10.1186/1471-2105-13-238.

\footnotetext{
Ready to submit your research? Choose BMC and benefit from:

- fast, convenient online submission

- thorough peer review by experienced researchers in your field

- rapid publication on acceptance

- support for research data, including large and complex data types

- gold Open Access which fosters wider collaboration and increased citations

- maximum visibility for your research: over $100 \mathrm{M}$ website views per year
}

At BMC, research is always in progress.

Learn more biomedcentral.com/submissions 